

\title{
THE IMPACT OF VOLUNTEER COMMUNITY SERVICE PROGRAMS ON STUDENTS IN TORONTO'S SECONDARY SCHOOLS
}

\author{
Agnes Meinhard and Mary Foster \\ Centre for Voluntary Sector Studies \\ Ryerson University
}

\section{Introduction}

One of the many challenges facing the nonprofit sector in Canada today is developing public awareness of the important role voluntary organizations play in the everyday lives of Canadians. Ranging from food banks, children's aid societies, and immigrant service organizations, to opera companies and sporting societies, nonprofit and voluntary organizations offer a startlingly wide array of services which cannot be adequately provided directly through the open marketplace or the state. There are approximately 200,000 nonprofit organizations, 75,000 of which are registered charities. They account for $12 \%$ of the country's GDP employing $5 \%$ of the national labour force and comprising nearly $10 \%$ of service sector employment (Stewart, 1996). In the past five years this sector accounted for $13 \%$ of job growth in Canada (Hall, 1996). The value of donated labour output was 13 billion dollars (Day and Devlin, 1996), representing an estimated half a million full time, full year jobs (Duchesne, 1989).

In the past five years in Ontario, the third sector has been experiencing radical changes as a result of government retrenchment. Whereas during the post-war decades there was close cooperation between governments and the voluntary sector, with many government programs encouraging the growth of the sector through the provision of grants, today the government is forcing the sector to seek their funding elsewhere. This has resulted in a significant increase in fundraising activities by voluntary organizations, whose success depends on the willingness of people to volunteer to help raise funds and to donate money.

This fiscal challenge is amplified by the fact that the nonprofit sector lacks the visibility and public awareness commonly accorded the private and government sectors (Salamon and Anheier, 1996). Canadians, used to easy, and for the most part free, access to government provided or government supported social services, were mostly unaware of the fact that a large portion of these services was provided by nonprofit organizations. Education about the contribution of the voluntary sector to the quality of life that Canadians enjoy is the primary tool to increase awareness. Without education, "the ethos of giving will fail to develop, regardless of changes in tax and other laws" (Salamon and Anheier, 1996:126). To be effective, education works best, if it starts early.

In 1996, we conducted a survey to ascertain what, if any, educational initiatives were in existence in Toronto's high schools with respect to community service (Meinhard and Foster, 1998). We found that almost half (46\%) of the 162 respondents representing Toronto's public, separate (Catholic) and private secondary schools had some form of community service programming in which students volunteered their time to the "third sector". However, in $60 \%$ of 
the schools these programs were generally the result of individual teacher initiatives and included, on average, only $10 \%$ of the student body. In $40 \%$ of the schools the program was mandatory in at least one of the grades.

In 1998-99 we received consent from 10 Toronto secondary schools to survey students who were currently participating in community service programs and control groups of students who weren't, once at the beginning of the school year and again at the end of term. This paper presents preliminary results of the survey.

\section{Review of Literature}

\section{The Changing Face of Volunteer Activity}

Historically, in North America and in Britain, volunteer behaviour - the active participation in helping the poor and the needy, as opposed to merely the giving of alms - was initiated and encouraged by religious institutions and formed the foundation of the social welfare services (Feingold, 1987; de Schweinitz, 1943). By the beginning of the twentieth century, helping the poor became more secularized and professionalized as social workers gradually replaced religious volunteers and congregational voluntary action declined (Cnaan, Kasternakis and Wineburg, 1993). The state formed a partnership with NPOs to provide the essential social services and volunteers were seen as adjuncts to the professionals. In Canada, during the halcyon postwar years governments encouraged the formation of nonprofit social service organizations providing professional care. They were to be part of an elaborate social welfare system, allies of the state, extending specialized services that the government was uninterested in or unable to provide. Not only did these organizations receive generous funding from government sources, but more importantly they also gained legitimacy to represent and serve their various constituencies (Tucker, Singh and Meinhard, 1990). However in the current political and philosophical climate of cutbacks and downloading, nonprofit organizations are in crisis, having to cut services and staff in order to survive (Foster and Meinhard, 1996; Meinhard and Foster, 1997). The contribution of volunteers is once again sought after and valued. Premier Mike Harris of Ontario, won a landslide victory on a platform that identified reliance on personal volunteering as part of his government's strategic reallocation of services in the framework of the "common sense revolution".

There is strong opposition to this emerging social philosophy. Both individuals and organizations, citing the high turnover rate and the subsequent high cost of constantly training volunteers, have presented the government with potent arguments against the devolution of social services from professionals to volunteers, (e.g., Lefebvre, 1996). Nevertheless, the reality is that government funding for social and cultural services has decreased substantially in the last few years (Barker, 1996 ). This has resulted in an attempt by social service organizations to avert cutting services by relying more on volunteers, either for help in providing services, or for fundraising purposes, where possible (Meinhard and Foster, 1997). Given the situation, these organizations may benefit from a larger and better educated pool of volunteers. 


\section{Community Service Programs}

Socializing children (and members of society as a whole) to the importance of community involvement and charitable giving is a key factor in this new social philosophy. This has traditionally been a role of religious institutions, as service to others and the obligation to helping the poor is central to all religious teaching (Feingold, 1987). Indeed, surveys of the determinants of voluntary action among teens have consistently pointed to the importance of parental example and religious affiliation as two of the strongest factors in predicting volunteer participation (Independent Sector, 1990). Teens, whose parents are volunteers and who are affiliated with organized religion in some form, are more likely to participate in volunteer activities.

In an increasingly secularized society, it is unrealistic to rely solely on religious institutions to socialize societal members to community involvement and social action. As a matter of fact, Wuthnow (1991) found that religious institutions' primary goals are to encourage members first and foremost to volunteer for the benefit of the congregation. This does not necessarily translate into increased volunteer activity for the general good. Cnaan and his associates (1993), in a thorough review of studies investigating the relationship between religious beliefs and volunteering found the evidence for a relationship inconclusive. In their own study, they found no relationship between intrinsic religious motivation and volunteer activity concluding that other factors may be important in determining volunteering.

These findings of course do not negate a role for religious institutions in encouraging and educating their members to have greater community commitment. However, they do indicate that in order to instill voluntary community commitment and involvement in our young people, other sources of socialization are needed. The three pillars of socialization in North America are home, school and religious institution. All three of these were found to have an influence on the volunteering behaviour of teenagers (Sundeen and Raskoff, 1994). A survey of American teenagers by Prudential (1995) attested to the importance of schools, parents and role models in motivating student interest in community service.

In the United States, the concept of service learning or community service in the schools dates back to the turn of the century to the writings of John Dewey who pointed to the "importance of social and not just intellectual development; and the value of actions directed towards the welfare of others" (Kraft, 1986:133). Service learning has been approached with renewed vigour in American schools in the past two decades. It is seen as an antidote to the decline in communal and civic participation witnessed over that past half century, as individualism has prevailed over community in the constant American struggle to balance the two (Barber, 1992; Bellah et al., 1985; Putnam, 1995).

A 1986 survey of 5,400 high schools found that $27 \%$ of them had some form of community service program (Newman and Rutter, 1986). Similarly a 1990 survey of volunteering by teenagers estimated that about one quarter of American high schools offered courses which included a component of volunteering for community service (Independent Sector, 1990; Sundeen and Raskoff, 1994). In contrast to these findings, in Los Angeles County, 82\% of schools, both public and private, have community service programs (Raskoff and Sundeen, 1989). 


\section{Benefits of Community Service Programs}

Theoretical models of service learning suggest "that community service may promote competence and self-esteem, reduce levels of problem behaviours, provide greater knowledge of community problems and advance cognitive and moral development in adolescents" (Moore and Allen, 1996:224) In their detailed review of 8 different surveys of community service programs at both the high school and university levels, Moore and Allen (1996:242) concluded that volunteering through school programs reduced failure and dropout rates, improved reading skills, self-concept and attitudes towards society. However, participation in these programs did not relate to "increases in social competence, career exploration, greater problem solving abilities, responsibility towards school, anticipated participation in politics or beliefs in the individual's responsibility to help people in need."

Kraft (1996:143) also reviewed evaluative studies of service learning programs. He concluded that there is "a lack of solid evidence on the effects of these programs" because it is "difficult to isolate the effects of service on specific academic achievements." He categorized the effects of service learning programs into five areas of impact:

a) social growth - the findings are mixed, some evidence that students become more service oriented, less prejudiced, more democratic, greater sense of social responsibility

b) psychological development - there is evidence that service learning programs have a positive effect on the development of a positive self-image, increased self-confidence and self-esteem.

c) moral judgment - the results are mixed, but there is some evidence of impact on moral judgment

d) academic learning - again there are mixed results. In general tests of knowledge there is usually no difference between service learners and the control groups, but on measures of reading and math achievement scores of tutors, there is improvement.

e) community served - there is evidence that young people have a positive impact on the community.

Presently in the United States, there is a major federally funded effort underway called "Learn and Serve America School and Community-Based Programs". The program was established in 1993 with the objective of involving "school aged youth in programs and classroom activities that link meaningful service in the community with a structured learning experience" (Melchior, 1997:1). "Service-learning stands in contrast to traditional voluntarism... (in that it includes)... reflection and links to organized curriculum" (Melchoir, 1997:11).

Approximately $\$ 30$ million in grants were awarded in the first year of the program to support 2000 local efforts involving more than 750,000 school-aged youth. The Center for Human Resources at Brandeis University is conducting a long-term evaluation of the impact of the program. In their initial article they reported statistically significant impacts on measures of personal and social responsibility, acceptance of cultural diversity and service leadership, with program participants scoring higher on all of these measures than nonparticipants. Program participants also volunteered their services more frequently and for longer hours. Interestingly the 
grade point averages, as well as other educational measures, showed greater improvement for participants than for nonparticipants (Melchior, 1997).

\section{Community Service in Canada}

The tension between individual pursuit of happiness and the good of the community that many scholars have remarked upon in the United States (Barber, 1992; Bellah et al., 1985, Putnam, 1995), is not a characteristic feature of Canada. As opposed to every individual's right to "Life, Liberty and the Pursuit of Happiness," as stated in the Declaration of Independence, the preamble of Canada's Constitution Act, 1867, talks of "Peace, Order and Good Government". It wasn't until the patriation of the constitution in 1982, that Canada had a written Charter of Rights outlining individual rights and obligations. For many historical reasons, in Canada, the common good generally took precedence over individual rights. In the struggle to keep the wide expanse of Canada together, the Canadian government was always more involved in the management of both the economy and the welfare of its citizens. Thus the partnership between the voluntary sector and the government took a different form in Canada from that in the U.S. (Shields and Evans, 1998). In fact, there is a widely held opinion that there really is no "third" sector in Canada, as voluntary social service organizations are viewed as part of the public sector because of the symbiotic nature of the relationship. It is the obligation of governments at all levels to support social services provided by professionals, regardless of the delivery mode, i.e. whether through a branch of government or through a government funded social service agency. This philosophy is only now beginning to unravel in the "name of fiscal restraint and the new competitive global order" (Shields and Evans, 1998:17). The deep-seated belief in a strong state role in society has been undermined, and has significantly changed the environment in which voluntary social service agencies must exist.

There have been no country wide initiatives in Canada such as the "Learn and Serve America" program, nor have there been the kind of nation-wide calls for the inclusion of community service programs in schools as issued in the U.S. by Goodlad (1984) and Boyer (1983) and the Carnegie Task force on Education of Young Adolescents (1989). Currently, the Ontario Ministry of Education is proposing to make participation in community service mandatory for all high school students in the province of Ontario. The recommendation was made with no systematic evaluation of the impact of community service on either participants or recipients. This study is the first attempt to collect information about the outcomes of adolescent participation in volunteer activities.

\section{Method}

\section{Design}

A quasi-experimental design was used with surveys distributed to experimental and control groups at the beginning of term and at the end of term. The experimental group consisted of those students who participated in the community service program in their school. The control group consisted of students in the same grade, either from the same school, or, in the case of schools where the program was mandatory, from a different but similar school. 


\section{Sample}

In the original survey to determine how many of Toronto's secondary schools had community service programs, the response rate was $85 \%$ (Meinhard and Foster, 1998). Approximately three quarters of the schools that had community service programs indicated that they would be willing to participate in a student survey. Unfortunately, the 1998-1999 school year opened with strikes in the separate (Catholic) schools and work-to-rule slowdowns in the public schools. This had a significant impact on participation rates in our survey. Many schools contacted in May and June 1998, which had agreed to participate in the study the following September, were either unavailable because of the strike, or forced to cancel because the work-to-rule orders specifically prevented teachers from participating in extracurricular activities, and many of the community service programs were considered extracurricular. We had considered postponing the student survey till the 1999-2000 school year, but with the new mandatory community service project legislated by the Ontario government coming on line in September 1999, to the dissatisfaction of the teachers, we could not postpone. Thus, our school sample consisted of only 10 schools: three public, 2 alternative public, 3 independent, and 2 separate (Catholic). In total, 467 students participated in the survey: 315 were in the experimental group; and 152 were in the control group. There was a $16.7 \%$ attrition rate making the final sample: 260 experimental; and 129 control.

\section{Survey Instrument}

We obtained permission from the researchers at Brandeis University to adapt or administer as is, the instrument that was used in the Learn and Serve America evaluation. It was based on existing attitudinal scales and questionnaires that were being used in studies of similar programs. Included are scales measuring service experience, educational competence, personal and social responsibility, acceptance of diversity, communication skills, work orientation, engagement in service learning, leadership, formal helping behaviour and self-esteem. The questionnaire was pretested on 233 respondents in May and June, 1998 (Meinhard and Foster, 1998). Revisions were made to the questionnaire as a result of the pretest analysis. (A copy of the revised questionnaire can be obtained from the authors.)

Students completed both the before and after questionnaires in a classroom setting with a member of the research team supervising. Students were advised that the survey was confidential and that only the researchers would have access to the completed questionnaires. The survey took between 20 and 30 minutes to complete.

\section{Results}

The students in this survey participated in programs that were either: a) purely voluntary; that is, there was no requirement for participation; or b) a substitute for taking a religion course in a separate school; or c) mandatory for a particular school, usually a private school.

The presentation of findings will focus on answering four key questions: 
1. What are the characteristics of community service activities in which students have participated? What was the usual design of a placement activity? Did students find the work they did meaningful?

1. Do students participating in community service activities take their placements seriously? Some respondents chose to participate, while others have to participate. Since this activity occurs off school premises, do students approach it as "time off" or with the same seriousness as school work?

2. What have been the perceived benefits, if any, for students? What do students take away from this experience?

3. What have been the perceived benefits, if any, for the community? What are the long-term consequences for the community?

\section{Characteristics of Community Service Activities}

Community service programs varied in terms of design and organization. Almost $45 \%$ of students reported working in placements that directly helped other people (eg. working in a nursing home or shelter, tutoring or mentoring) and $40 \%$ participated in activities that indirectly helped other people (eg. raising money or collecting food or clothing for people in need). The balance (15\%) report working in placements that helped the community in general (eg. recycling cans, cleaning a park or getting signatures on a petition). The activities in which they were involved included: educational (46\%), helping people in need (47\%), keeping the environment clean $(23 \%)$, public safety activities $(11 \%)$ and other kinds of activities $(49 \%)$. (The percentages add up to more than $100 \%$ because the students were asked to check all that applied.)

Thirty-six percent of students selected or designed their own placement activities and $62 \%$ had activities assigned to them. The majority (53\%) participated in activities that included both team and individual work. Thirty-one percent classify their placement as team work only and $15 \%$ as individual work only.

What appeared to be missing from these programs was adequate follow-up. This may have been a consequence of the workload dispute between the teachers and the Boards of Education which resulted in withdrawal by teachers from supervising extra-curricular activities. For $80 \%$ of students, there was no opportunity to discuss their experiences in class. Only $12 \%$ of students were required to keep a diary as part of their voluntary service project.

Another important design consideration is the content of the program. If the long-term goal of high school participation in community service is to engender a life-long commitment to the voluntary sector, then the quality of the initial experience is pivotal. In general almost half of students reported experiencing a very meaningful placement, but between one-quarter and one-third did not describe their experience in positive terms.

As Table 1 indicates almost half of the students (45\%) report having real responsibilities and challenging tasks in their volunteer placements. Although only one-third felt they made important decisions, $44 \%$ felt their placement involved doing things instead of merely observing 
others, $42 \%$ felt they had the freedom to use their own ideas, $39 \%$ were able to explore their own interests and $47 \%$ reported having a variety of tasks to do.

Table 1. Perceived Features of Volunteer Experience $\quad(n=242)$

\begin{tabular}{|c|c|c|c|}
\hline \multirow{2}{*}{$\begin{array}{l}\text { Perceived Features of Volunteer } \\
\text { Experience }\end{array}$} & Rarely & Sometimes & Often \\
\hline & $\%$ & $\%$ & $\%$ \\
\hline Had real responsibilities & 17 & 28 & 45 \\
\hline Had challenging tasks & 23 & 31 & 45 \\
\hline Made important decisions & 35 & 33 & 32 \\
\hline Did things myself instead of observing & 24 & 32 & 44 \\
\hline $\begin{array}{l}\text { Had freedom to develop and use my } \\
\text { own ideas }\end{array}$ & 31 & 26 & 42 \\
\hline $\begin{array}{l}\text { Had freedom to explore my own } \\
\text { interests }\end{array}$ & 32 & 28 & 39 \\
\hline Had a variety of tasks to do at the site & 22 & 31 & 47 \\
\hline $\begin{array}{l}\text { Discussed my experiences with } \\
\text { teachers }\end{array}$ & 66 & 24 & 10 \\
\hline $\begin{array}{l}\text { Adults at the site took a personal } \\
\text { interest in me }\end{array}$ & 35 & 29 & 35 \\
\hline Needed more help from my supervisor & 70 & 23 & 6 \\
\hline Adults criticized me or my work & 81 & 14 & 5 \\
\hline $\begin{array}{l}\text { Discussed my experiences with family } \\
\text { and friends }\end{array}$ & 36 & 24 & 40 \\
\hline
\end{tabular}

Unfortunately, the role of adults in this experience appeared to be "hands off". Only $10 \%$ discussed their experience with their teachers and only slightly over a third felt the adults at the volunteer site took a real interest in them. Few students felt they needed help from their adult supervisor $(6 \%)$ and even fewer felt that the adults criticized them or their work (5\%). The impact of this role or non-role of adults in this experience is evidenced by the significant negative shift in attitude from pre-placement to post-placement about the perceived supportiveness of adults for student efforts to work on community problems. Whereas in the pre-placement questionnaire only $20 \%$ of students thought adults were not supportive, this increased to $30 \%$ post-placement. $(\mathrm{p}<.009)$. 


\section{Do Students Take Placements Seriously?}

In general, $86 \%$ of the students felt that it was important to do one's best when planning or working on community service activities; for $45 \%$ this was very important. The data in Table 2

Table 2. Comparison of Work Ethic Towards School and Toward Community Service Pro

\begin{tabular}{|l|c|c|}
\hline \multirow{2}{*}{ Statements About School and Community Service } & True & Not True \\
\cline { 2 - 3 } & $\%$ & $\%$ \\
\hline When I am in class, I try very hard & 78 & 22 \\
\hline $\begin{array}{l}\text { When I am working on my community service activities, I } \\
\text { try very hard. }\end{array}$ & 77 & 23 \\
\hline I work very hard on my school work. & 85 & 15 \\
\hline $\begin{array}{l}\text { When I am planning my community service activities, I } \\
\text { work very hard. }\end{array}$ & 69 & 30 \\
\hline I try to learn as much as I can about my school subjects & 73 & 27 \\
\hline $\begin{array}{l}\text { I try to learn as much as I can about my community } \\
\text { service. }\end{array}$ & 67 & 33 \\
\hline When I am in class, I act as if I am working. & 36 & 64 \\
\hline $\begin{array}{l}\text { When I am planning or working on my community } \\
\text { service, I just act as if I am working. }\end{array}$ & 21 & 79 \\
\hline I pay attention in class. & 78 & 22 \\
\hline $\begin{array}{l}\text { I pay attention when planning or working on my } \\
\text { community service activity. }\end{array}$ & 83 & 16 \\
\hline When I am in school, I am happy. & 62 & 38 \\
\hline $\begin{array}{l}\text { When I am planning or working on community service } \\
\text { activities, I am happy. }\end{array}$ & 77 & 23 \\
\hline
\end{tabular}

suggest that students view their community service activities with at least the same level of seriousness and commitment with which they view their school work.

The only exceptions in this pattern are planning and learning about community service activities. Thirty percent report not working hard on planning these activities and one-third report not learning as much as they can. This may be attributed to the fact that $62 \%$ had their activity assigned to them; and thus, could take no major role in planning.

Interestingly, fewer students report acting as if they are working in their community service, 
than report acting as if they are working in class (21\% vs. 36\%). Similarly, more students report paying attention when planning or working on their community service activity compared to paying attention in class (73\% vs. $67 \%)$. Finally, $77 \%$ of students report being happy when planning or working on community service activities, compared with $62 \%$ who report being happy in school. This suggests that the opportunity to do meaningful service may help motivate uninterested students to stay in school, which is consistent with Moore and Allen (1996).

\section{Perceived Benefits for Students}

Overall, $83 \%$ of students were satisfied with their volunteer service experience with one-third being very satisfied. Almost two-thirds (63\%) felt they learned a skill that will be useful to them in the future. However, only $23 \%$ felt their service helped them think about the kind of job they might want and only $21 \%$ felt their service helped them learn more about a career in which they thought they might be interested. When they compared their voluntary service experience to a typical class they've taken in school, $30 \%$ felt they learned more than in a typical class, $37 \%$ the same and $32 \%$ less. Interestingly, while $84 \%$ felt that students should be encouraged to participate in volunteer programs, a good majority (58\%) were against a compulsory requirement to participate.

Table 3. Self-esteem items on which significant differences (at least $p<.01$ ) were observed between experimental and control groups post-placement as well as between pre and post-placement scores in the experimental group

\begin{tabular}{|l|c|c|c|}
\hline \multirow{2}{*}{ Self -esteem items } & \multicolumn{2}{|c|}{ \% who strongly agree with statement } \\
\cline { 2 - 4 } & \multicolumn{2}{|c|}{ Post-placement } & Pre-placement \\
\cline { 2 - 4 } & $\begin{array}{c}\text { Control } \\
(\mathrm{n}=129)\end{array}$ & $\begin{array}{c}\text { Experimental } \\
(\mathrm{n}=260)\end{array}$ & $\begin{array}{c}\text { Experimental } \\
\text { (n=315) }\end{array}$ \\
\hline $\begin{array}{l}\text { To me, success is not imperative, the } \\
\text { important thing is to try and do my best }\end{array}$ & 25 & 50 & 27 \\
\hline I deserve to be loved and respected & 72 & 85 & 72 \\
\hline $\begin{array}{l}\text { On the whole, I am satisfied with myself } \\
\text { I feel I can make mistakes without losing }\end{array}$ & 55 & 71 & 48 \\
\hline the love and respect of others
\end{tabular}

Just as Kraft (1996) and Melchior (1997) found in their research on community service programs in the US, we too found that participation in community service activities seems to have a 
significant positive impact on the self-esteem of high school students. Participants were significantly more likely post-placement and compared to non-participants to agree that: a) the most important thing is to do one's best; b) they deserve to be loved and respected; c) they are satisfied with themselves; d) they can make mistakes without losing love and respect; and e) they don't need the approval of others to be happy and satisfied (at least $p<.01$ on all items listed).

\section{Perceived Benefits for the Community}

Although the study did not survey the community or the recipients of the service to identify the impact of high school students' being involved in volunteer service, the questionnaire did ask respondents about their perception of their contribution. The majority of students (60\%) felt that they often made a contribution, 23\% said sometimes and only $17 \%$ felt that they had little impact.

Eighty-four percent felt that the service they performed was helpful to the community and $88 \%$ felt it was helpful to the individuals they served.

With respect to the long-term goal of helping adolescents develop a life-long commitment to community service, the results are very encouraging. Almost two-thirds (65\%) indicate that as a result of their community service experience, they are committed to community service now and later in life. There is also evidence that these intentions have been translated into behaviour in that $54 \%$ report already having done additional volunteering over and above their community placement activities.

\section{Discussion}

When this study was conceived in 1996, there was no public discourse with respect to introducing community service as a mandatory part of the curriculum of Ontario's high schools. In fact, our initial survey revealed that fewer than half of Toronto's high schools had community service programs and among Toronto's public schools, the ratio of schools with volunteer programs was just over one third. Only $17 \%$ of schools that didn't have the program indicated that they were considering one on the future. Clearly, community service was not considered an educational priority. All this changed with the announcement by Ontario's Minister of Education mandating Ontario's high schools to introduce compulsory community service for students starting September 1999 (Globe and Mail, January 10, 1998). "In order to encourage civic responsibility and promote community values, all students will be required to complete a minimum of 40 hours of community involvement prior to high school graduation" (Government of Ontario, 1999).

Because of the implementation of this new policy initiative, the present study is timely. On the whole, the results indicate that volunteering in the community was a positive experience for most students. As demonstrated in previous studies, community service not only teaches students responsibility and provides them with new experiences, but it also has a positive effect on self esteem (Melchior, 1997; Kraft, 1996). 
However, our study also hints at some disturbing issues that may be perpetuated and even exacerbated in the newly mandated programme. We found an overall lack of adult participation in the students' community work in that students didn't discuss their experiences with teachers, nor did they have meaningful relationships with adults at their volunteer site. This had a negative impact on their evaluation of adult supportiveness of their efforts. Without the benefit of a longitudinal study, it is impossible to gauge the long term effects of this. However, Raskoff and Sundeen (1998) point to the importance of forging partnerships among the schools, the students and voluntary agencies in order to achieve the greatest benefit for both the student and the community. Clearly this is not the model foreseen by the Ontario government. According to the new government program, students are "responsible for fulfilling their community involvement requirement on their own" (Government of Ontario, 1999).

Another disturbing finding in our study is the lack of opportunity for students to share their experiences in class. This indicates that there was no integration of the community service with a structured learning experience that is such an integral part of the "Learn and Serve America" program (Melchior, 1997). Discussing volunteer experiences in the classroom would allow students to learn from others' experiences and broaden their own knowledge of the community and voluntary agencies. It is unclear whether the new government curriculum intends to integrate volunteer activity with classroom discussion. However, the way the program is described, with a general requirement for students to complete 40 hours of service over a four year period, it doesn't seem as if there will be opportunity for integration.

There has been some criticism regarding the minimal lead time allowed for the implementation of the new curriculum. The government clearly expects that voluntary organizations will be a major source of placements (Government of Ontario, 1999). Representatives of voluntary organizations, particularly volunteer centres, whose job it is to match volunteers to appropriate organizations are worried that: a) there is not enough time prepare themselves for the large influx of students; and b) more importantly, individual voluntary organizations will not be sufficiently prepared to provide students with a meaningful volunteer experience. They fear that a poorly planned placement will have an effect that is opposite to the one desired. Instead of increasing commitment to volunteering and creating positive perceptions of the third sector, students will be left with negatives feelings and experiences. Indeed, our findings show that almost one third of the students participating in current programs did not describe their experience in positive terms. Follow-up analysis will attempt to determine whether this is a result of their placement.

\section{Conclusions}

Our findings unequivocally demonstrate that voluntary service to the community has a beneficial impact on participants in many different ways. However, this study discloses some weaknesses in the structure of most of the high school programs as they existed in the past. We suggest that these points be considered when the new Ministry of Education program is implemented in Ontario's high schools. The fact that one quarter to one third of the students did not describe their experience as positive is disturbing. It points to the importance of carefully structuring a community service program by: a) forging partnerships between schools and 
voluntary agencies so that optimal placements can be assured to students and b) providing opportunities for students to share their experiences with their teachers and peers in a classroom setting which allows integration of their community endeavours with their formal learning activities.

\section{References}

Barber, B. (1992). An Aristocracy of Everyone. New York: Ballantine.

Bellah, R., Madsen, R., Sullivan, W., Swidler, A. \& Tipton, S. (1985). Habits of the Heart. Berkeley: University of California Press.

Boyer, E. (1983). High School. New York: Harper and Row.

Carnegie Task Force on Education of young Adolescents. (1989). Turning Points: Preparing American youth for the 21 st century. New York: Carnegie Council on Adolescent Development of the Carnegie Corporation.

Cnaan, R., Kasternakis, A. \& Wineburg, R.J. (1993). Religious people, religious congregations, and volunteerism in human services: Is there a link? Nonprofit and Voluntary Sector Quarterly, 22 (1): 33-51.

Day, K.M. \& Devlin, R.A. (1996). The Canadian nonprofit sector, in Hirshhorn (Ed.), The Emerging Sector: In Search of a Framework. Ottawa: Canadian Policy Research Networks Inc.

de Schweinitz, K. (1943). England's Road to Social Security. New York: Barnes.

Duchesne, D. (1989). Giving Freely: Volunteers in Canada. Statistics Canada, Labour Analytic Report, Cat. 71-535 No. 4. Ottawa: Minister of Supply and Services

Feingold, Mordechai (1987). Philanthropy, pomp and patronage: Historical reflections upon the endowment of culture. Daedalus, 116 (1): 155-178.

Foster, M.\& Meinhard, A. (1996). Toward Transforming Social Service Organizations in Ontario. Presented at Babson Conference on Entrepreneurship, Seattle, WA.

Globe and Mail. (1998) January 10, page 1.

Goodlad, J. (1984) A Place Called School. New York: McGraw-Hill.

Hall, M. (1996). Comment, in Hirshhorn (Ed.), The Emerging Sector: In Search of a Framework. Ottawa: Canadian Policy Research Networks Inc.

Independent Sector. (1990). Volunteering and Giving Among American Teenagers 14 to 17 Years of Age: Findings from a National Survey. Independent Sector, Washington, DC. 
Kraft, Richard (1996). Service learning: An introduction to its theory, practice and effects. Education and Urban Society, 28 (2): 131-159.

Lefebvre, B. (1996). From minutes of the Standing Committee on General Government, Government of Ontario. Timmins Ont.: June 16, 1996.

Meinhard, A.\& Foster, M. (1997). Responses of Women's Voluntary Organizations to the Changing Social, Political and Economic Environment. Presented at the 26th Annual ARNOVA Conference, Indianapolis, IN.

Melchior, A. (1997). National Evaluation of Learn and Serve America School and Community-Based Programs: Interim Report. Unpublished Manuscript.

Moore, C.W. \& Allen, J.P. (1996). The effects of volunteering on the young volunteer. The Journal of Primary Prevention, 17 (2): 231-258.

Newman, F.M. \& Rutter, R.A. (1986). Profile of high school community service programs. Educational Leadership, 43 (4): 65-71.

Prudential. (1995). Prudential Spirit of Community Initiative: Highlights of the Youth Survey of Community Involvement.[Online] http://www.prudential.com/community/spirit/cmszz1004.html

Putnam, R.D. (1995). Bowling alone: America's declining social capital. Journal of Democracy, 6 (1): $65-78$.

Salamon, Lester M. \& Anheier, Helmut K. (1996). The Emerging Nonprofit Sector: An Overview. Manchester: Manchester University Press.

Stewart, W. (1996). The Charity Game: Waste and Fraud in Canada's \$86-Billion-a-Year Compassion Industry. Toronto: Douglas \& McIntyre.

Sundeen, R. \& Raskoff, S. (1994). Volunteering among teenagers in the United States. Nonprofit and Voluntary Sector Quarterly, 23 (4):383-403.

Toronto Star. (1997) November 13, Final Edition: C2.

Toronto Star. (1998) January 4, Final Edition: F6.

Toronto Star. (1998) February 18, Final Edition: A1.

Tucker, D.J., Singh, J.V. and Meinhard, A.G. (1990). Organizational form, population dynamics and institutional change: A study of birth patterns of voluntary organizations. Academy of Management Journal, 33:151-178.

Weinrich, P. (1996). The Third Sector. http://www.volunteer.ca/3rdsectr.htm 
Wuthnow, R. (1991). Acts of Compassion: Caring for Others and Helping Ourselves. Princeton, NJ: Princeton University Press. 